\title{
STM によるワイル半金属表面でのフェルミアーク観察
}

\author{
井上 博 之*
}

（2018 年 5 月 12 日受付；2018 年 7 月 12 日掲載決定）

\author{
Observation of Surface Fermi Arcs in Weyl Semimetal via Scanning Tunneling Microscopy \\ Hiroyuki INOUE*
}

(Received May 12, 2018 ; Accepted July 12, 2018)

\begin{abstract}
Weyl semimetals host topologically protected surface states, with arced Fermi surface contours that are predicted to penetrate through the bulk when their momentum matches that of the surface projections of the bulk's Weyl nodes. Here, we describe our experiment in which we used spectroscopic mapping with a scanning tunneling microscope (STM) to visualize quasi-particle interference at the surface of the Weyl semimetal TaAs. Our measurements revealed multitude of scattering wavevectors, which can be reproduced by taking into account the shape and spin texture of the Fermi arc surface states and their momentum-dependent penetration into the bulk. Our result exemplifies an atomicscale manifestation of surface-bulk connectivity of Weyl semimetal.
\end{abstract}

KEYWORDS : Weyl semimetal, Fermi arcs, scanning tunneling microscopy, surface science, topological materials

\section{1. は じめ に}

「物質のトポロジカル相とトポロジカル相転移の 理論的発見」の業績に対してD. J. Thouless, F. D. M. Haldane, J. M. Kosterlitzの三氏に 2016 年ノーベル物理 学賞が贈られた事はまだ記憶に新しい。80 年代に始ま ったトポロジカル物質相の研究は, 波動関数の位相のト ポロジーと言う視点を物質研究にもたらし, 物質相分類 の新たな枠組みを建設して来た。

これまでトポロジカル物質として既に様々な系が実現 されて来たが, ワイル半金属と呼ばれる物質が近年注目 を集めている ${ }^{1)}$ 。ワイル半金属はフェルミ面付近の電子 が相対論的量子力学で提案されたワイルフェルミオンと して振る舞う物質である。興味深い事に, 結晶のバルク (内部）のワイルフェルミオンの存在がサンプル表面に フェルミアークと呼ばれる「開いたフェルミ面」を持つ 表面状態を保証する事が理論的に提案された ${ }^{2 \sim 4)}$ 。そし て実際に角度分解光電子分光 (Angle-Resolved Photoemission Spectroscopy, ARPES）を用いて TaAs（タンタ ル砒素）の [001]面 ${ }^{4}$ でワイルフェルミオンとフェルミア

*E-mail : hiroyukiinoue1444@gmail.com
ークが観測された ${ }^{5 \sim 7)}$ 。本稿では, 超高真空内で TaAs を 䢃開し得られた清浄な [001]面に対し，原子スケールの 空間分解能を持つ走査トンネル電子顕微鏡 (Scanning Tunneling Spectroscopy, STM) を用いてワイル半金属の バルクと表面状態の結合性を捉えた我々の実験を紹介し たい ${ }^{8)}$

\section{2. トポロジカル物質と保護された表面状態}

無知の露呈を恐れずに言えば，トポロジーとは物の形 を連続的に変えた時に変わらない性質を扱う数学であ る。頻繁に挙げられる例はドーナッツの穴の様に連続な 変形によって変わらない性質であり, トポロジカル不変 量と呼ばれる。では, トポロジーの考え方が結晶電子に どのように活かせるのだろうか。結晶電子の分散関係は バンド構造と呼ばれ，結晶の周期性を反映して波数（結 晶運動量）空間はブリルアンゾーンを単位とした周期性 を持つ。バンド構造は格子定数やスピン軌道相互作用な ど結晶のパラメーターに応じて変化し, バンドの形状, 位置, バンド交差が変化する。このバンド交差がトポロ ジカル物質の議論では鍵となる。ここで Fig. 1 の赤と青 の点を後程説明するワイル点として捉えよう。結晶のパ ラメーターを $\Delta$ とすると, 系は $\Delta$ のある領域でトポロ 


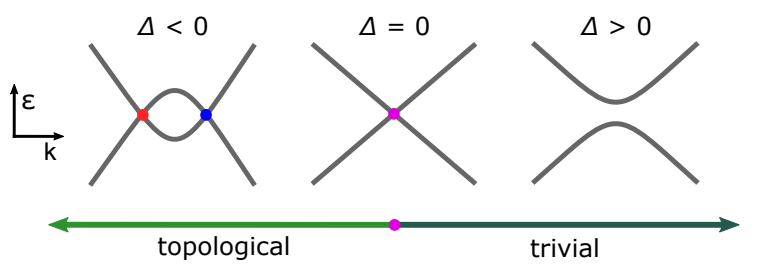

Fig. 1. (color online). A schematic evolution of band crossings as a function of a crystal parameter $\Delta$. When $\Delta<0$ $(\Delta>0)$, the system is in topologically nontrivial (trivial) phase with $\Delta=0$ being the critical point between the phases. Red and blue points represent Weyl points.

ジカルに非自明な構造を生むバンド交差を保ち，それ以 外ではバンド交差が解けてトポロジカルに自明な系とな る9)。重要な点は, トポロジカルな性質は $\Delta=\Delta_{0}$ など パラメーターの一点ではなく, ある範囲に亘って保たれ る事である。

トポロジカル物質の更に興味深い性質は, 系の表面に バルクの性質を反映した表面状態を持つ点である。サン プル外の真空はトポロジカルに自明な系であり, Fig. 1 の $\Delta>0$ の領域に対応する絶縁体とみなして良い。サン プル内が $\Delta<0$ というトポロジカルに非自明な領域にあ る時, サンプルの内側から外側へ移行する際，必ず $\Delta$ $=0$ の状態を経由する。この $\Delta=0$ の状態は表面状態に 他ならず，サンプルの内側がトポロジカルに非自明な限 り, 取り除く事ができない。このような表面状態の事を トポロジカルに保護された表面状態と呼ぶ。サンプルの 形状を変えるなど境界を動かす事が出来てもそのような 表面状態は存在し続ける。本稿で紹介するワイル半金属 はペアのワイル点を繋ぐようなフェルミアークと呼ばれ る表面状態を持つ（Fig. 2 (a)）。

\section{3. ワイル半金属}

1929 年, H. Weyl はディラック方程式の粒子質量がゼ ロとしたワイル方程式を発表した。このような質量ゼロ の粒子をワイルフェルミオンと呼ぶ。ワイルフェルミオ ンは早くから理論的には提案されていたが, 現在まで素 粒子物理学の領域では発見に至らなかった。

それ故に, 近年固体結晶中においてワイルフェルミオ

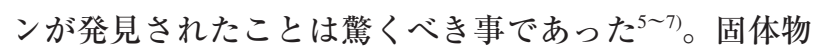
理学が扱う対象は, 相刘論的なエネルギースケールに比 べると遥かに小さなエネルギースケールであり, 前述の ディラックフェルミオンやワイルフェルミオンとは一見 無縁の世界の様に思える。しかしながら, 結晶格子上の 電子は結晶構造を反映したバンド構造を持つため, 様々 な性質が発現する肥沃な土壤であり, ワイルフェルミオ ンの性質を持つ電子さえ現れ得るのである。2つの縮退
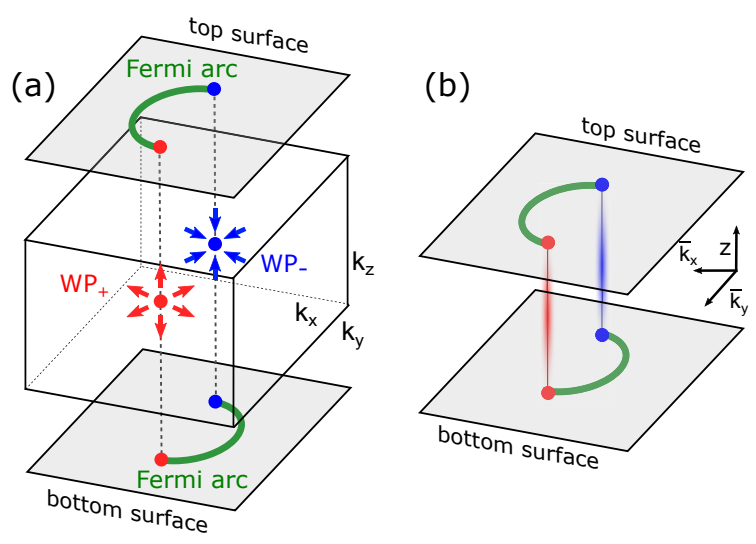

Fig. 2. (color online). Schematic illustration of Weyl points and Fermi arcs (a) The central box represents the first Brillouin zone in the momentum space. The red (blue) Weyl point (WP+) carries a positive (negative) chirality. Projections of Weyl points on to the top and bottom surface in the real space are connected to the edges of surface Fermi arcs. (b) A quantum trajectory that involve both bulk Weyl points and Fermi arcs on the top and bottom surfaces. Notice that the vertical axis is a real-space axis.

のないバンドがある 1 点で線形に交差する時, この点交 差付近の電子はワイルフェルミオンとして振る舞う。こ の点交差はワイル点と呼ばれ, 近傍の線形分散部はワイ ルコーンとよばれる。等方的なワイルフェルミオンの場 合, 一つのワイル点周りのワイルフェルミオンのハミル トニアンは $H=v\left(k_{x} \sigma_{x}+k_{y} \sigma_{y}+k_{z} \sigma_{z}\right)$ となる。ここで $v$ はフ エルミ速度, $k_{x}, k_{y}, k_{z}$ はワイル点から測った波数べク トルの各成分， $\sigma_{x}, \sigma_{y}, \sigma_{z}$ はパウリ行列であり, 粒子的 バンドと正孔的バンドの自由度を表す。ここでこれらは スピン縮退の無いバンドである点に注意されたい。3次 元の空間に現れるこのワイルフェルミオンは 3 つのパウ リ行列が波数を係数に持つため, 摂動（結局パウリ行列 に比例する）を加えてもワイル点は移動するだけで取り 除く事は出来ない。グラフェンで現れるディラックフェ ルミオンは, 系が時間・空間反転対称性を持つためにス ピン縮退したバンドの点交差から生まれる4成分の線形 分散を持つ電子である。しかし，ハミルトニアンは空間 の 2 次元性のため 2 つのパウリ行列が波数を係数に持 ち, 例えば副格子の空間対称性を破る摂動が加わるとデ イラック点は失われてしまう。ワイル半金属は 3 次元版 グラフェンとも呼ばれる事もあるが, 上述の様な違いが ある。

特筆すべきはワイル点は波数空間の特異点として振る

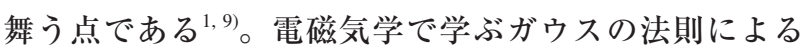
と, 点磁荷を中心に球面上を貫く磁束フラックスの積分 は磁荷量に比例する。同じ意味で, ワイル点は運動量空 間の「磁気単極子」として振る舞い, 波数空間に仮想的 
(a)

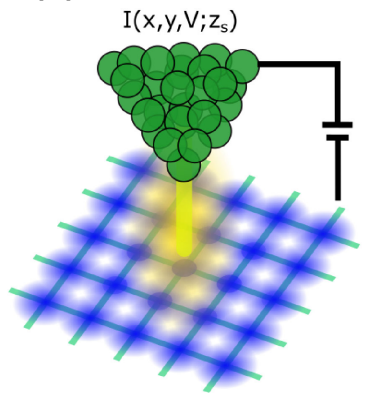

(b)

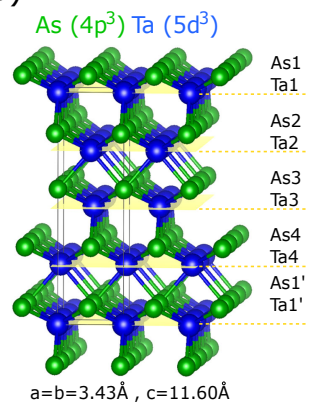

(c)

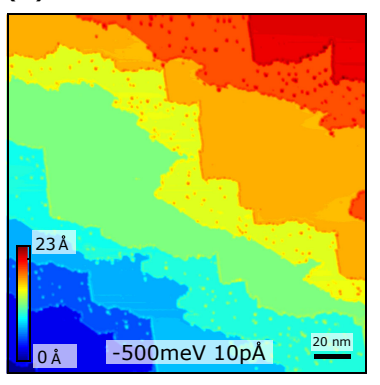

(d)

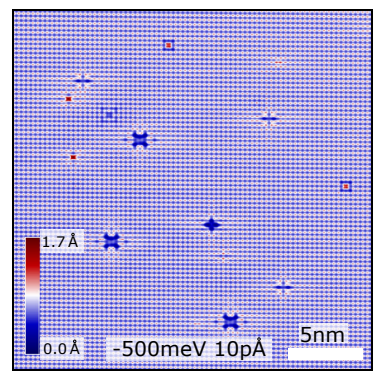

Fig. 3. (color online). (a) Schematic illustration of scanning tunneling microscopy rastering on a sample surface. (b) Crystal structure of TaAs with As termination along [001] surface. The lattice constants are $\mathrm{a}=\mathrm{b}=3.43 \AA$ along the a and $\mathrm{b}$ axes and $\mathrm{c}=11.60 \AA$ along the $\mathrm{c}$ axis. The $\mathrm{c}$ axis contains 4 layers of As/Ta layers. (c) Topographic image of Asterminated [001] surface taken with the set condition of $V s=-500 \mathrm{meV}, \quad I s=10 \mathrm{pA}$. The step height was found to be $2.72 \AA$, which coincides with 1 layer of As/Ta layers. (d) Topographic image of smaller area taken with the same conditions. An ordered As square lattice and various types of impurities therein are visible.

な磁場を産み出す。磁場はある種の空間の歪み（ゲージ 場）として表現できる。その仮想的な磁束密度をワイル 点を囲む球面に対して積分すると,「磁荷」に対応する 整数值のトポロジカル数が得られる（チャーン数と呼ば れる)。Fig. 2 に示す様に運動量空間の磁気単極子とし てのワイル点も同様に磁気双極子のように正負ペアで現 れる事が知られている。ワイルフェルミオンはデイラッ クフェルミオンがヘリシテイ正負の部分に分裂したもの と考えるとペアで現れる理由が直観的に分かると思う。

一つのワイル点に着目すると系はトポロジカルに非自 明で，保護された表面状態を持つ。一方，ペアを包むよ うな球面を考えると, 球の内部のトポロジカル数の総和 は 0 となり, 保護された表面状態は現れない。結果, 正 負のトポロジカル数を持つワイル点がペアで存在する帰 結は, ワイル半金属表面に射影したワイル点の間を繋ぐ ようなトポロジカルに保護された表面状態が現れる事で ある（Fig. 2（a)）。この保護された表面状態をフェルミ アークと呼ぶ2)。

フェルミアークがアークと名のついた理由は表面に射 影されたワイル点を慗ぐアークのように「開いた」形を 持つ為である。通常，アークの様に開いたフェルミ面が 現れる事はない。ではなぜそれが可能なのか。フェルミ アークの端は射影されたワイル点の位置に対応してお り, 仮に電子がフェルミアーク上を移動した時, 最終的 に端で溜らず, バルクのワイル点へ移行できる。これを 電子の表面からバルクへの「染み出し」と考えると, ワ イル点に近づく程, フェルミアーク上の電子の染み出し は大きくなる。このようなフェルミアークとワイルコー ンが繋がっている状況を表面バルク結合性と呼ぶ (Fig. 2(b))。

\section{4. 走査トンネル顕微鏡と準粒子干渉}

トポロジカル物質の実験的研究には ARPES や STM に代表されるような超高真空を要求する表面プローブが 重用されて来た。典型的には, 超高真空内でバルクの結 晶を䢃開して得られる清浄な表面を測定対象とする。磁 性を持つイリジウム酸化物結晶 ${ }^{2}$ や超格子系 ${ }^{3}$ はワイル半 金属として当初提案されたものの, 合成が難しく観測に は至らなかった。そんな中, 非磁性で空間反転対称性が 破れたストイキオメトリックな遷移金属モノニクタイド である TaAs, TaP, NbAs, NbP が提案され4), TaAs が 初のワイル半金属結晶の例となった。バルクにギャップ が開いたトポロジカル絶縁体と違い, ワイル半金属では 表面のフェルミアークとバルクのワイルフェルミオンが 結合している事が特徴である。表面とバルクの両者を巻 き込む表面-バルク結合性を反映した電子輸送現象が Vishwanath 等によって指摘された ${ }^{10,11}$ 。より具体的に は, ワイル半金属薄膜系にて, 上下表面のフェルミアー クがバルクの正負のワイル点で繋がれた量子軌道である (Fig. 2（b））。本実験では原子スケールの空間分解能を 持つSTM を用いてワイル半金属 TaAS での表面-バルク 結合性の現れを捉えることに成功したと考えられる。

STM では金属探針を用いて, サンプル表面に対して セット電圧 Vs とセット電流 Is を固定し, トンネル電流 Iにフィードバックを掛け，探針を走查する事で原子ス ケールの分解能を持ったイメージングを行う（Fig. 3 (a)）。本実験で使用した STM は $10 \mathrm{~K}$ から $120 \mathrm{~K}$ 程度ま で安定した可変温度測定ができるHo スタイルの可変温 度 STM である。トンネル電流は電圧を決めると, 探針 とサンプル表面間の距離に指数関数的に依存するため, $\mathrm{pm}$ スケールで距離を調節しながら走查する事が可能で 
ある。更に重要な点として, トンネル電流はサンプルの 局所状態数に比例する。局所状態密度はあるエネルギー におけるバンド構造上の状態数であり, 局所状態数は設 定した電圧に亘る局所状態密度の積分である。このよう にして得られる像をトポグラフ像と呼ぶ。測定では $I-V$ 測定（伝導測定）を行うと同時に，ロックイン法によっ $\tau \mathrm{d} I / \mathrm{d} V$ 測定（微分伝導測定）も行う。探針側の状態密 度が一定と考えらえれるならば，後者はサンプルの局所 状態密度に比例した量を測定していると考えて良く, STM を用いたサンプルの局所スペクトロスコピーを行 っている事になり, 走查トンネルスペクトロスコピー (Scanning Tunneling Spectroscopy, STS) とも呼ばれる。 また, STM を用いる利点は, 原子スケールで平坦な領 域が発見できればサンプルの中でも素性の良い領域を選 択的に測定可能な点である。仮に，表面が久陥の無い完 全な格子を成しているならば，STSによって得られる情 報は単位格子内の変動が周期的に現れるのみで, 局所状 態密度マップのフーリエ変換にはブラッグピークのみが 現れる。興味深い状況は不純物近傍である。不純物によ って電子（準粒子）が散乱され定在波が生まれることに より, 局所状態密度に格子周期とは異なる変調が生まれ る。定在波は二つの進行波が干渉する事で現れるが，表 面バンド構造上の電子散乱チャネルを反映した定在波が 生まれる。これを準粒子干渉（QPI）と呼ぶ。バルクト ポロジカル物質に対する STM 測定ではこの準粒子干涉 （QPI）が観測目標となる ${ }^{12,13) 。 ~}$

QPI はバンド構造上の異なる波数状態間の弾性散乱に より生まれる。入射波を $\boldsymbol{k}_{i}$, 散乱波を $\boldsymbol{k}_{f}$ とすると, QPI によって得られる情報は直接的なバンド構造ではなく, 可能な散乱べクトル $\mathbf{q}=\boldsymbol{k}_{i}-\boldsymbol{k}_{f}$ の分散である。一方, エ ネルギー分解された伝導度マップのフーリエ変換である FT-STS を近似的にシミュレーションする際に頻繁に用 いられる計算法はJDOS（Joint Density of States）と呼ば れる ${ }^{8}$ 。全ての状態間で等しく弾性散乱が起こると仮定 して, バンド計算により得られたバンド構造の自己相関 を各エネルギーで取る方法である。JDOS の計算には実 際に二つの状態間で散乱がどの程度可能かという事を一 切無視している事に注意されたい。FT-STS とJDOSを 比較する事で抑制された散乱チャネルの同定が可能にな る事がある。つまり, JDOS では存在するピークやパ夕 ーンが，測定された FT-STS では現れていないとする と，そのような散乱チャネルが実際には抑制されている と理解できる。例えば， スピン軌道相互作用によって表 面電子が波数に依存したスピン偏極を持っているような 場合，ある二つの状態間の散乱はスピン偏極の重なり 積分に比例した抑制を考虑する必要がある。つまり，ス
ピンが平行なら抑制無し，スピンが反平行なら完全に 抑制され，スピンの間の角度のコサインに比例して抑 制される。これはスピン依存散乱確率 (Spin-dependent Scattering Probability, SSP) を取り入れたJDOS として, SSP-JDOS と呼ばれる（以後，単にSSP と呼ぶ）。

\section{TaAs[001] 表面の STM 観察}

TaAs の結晶構造を Fig. 3（b）に示す。格子定数は a $=\mathrm{b}=3.43 \AA, \mathrm{c}=11.60 \AA$ である。空間群 $\mathrm{I} 41 \mathrm{md}$ に属 し，反転対称中心は持たず， $\mathrm{c}$ 軸に沿ってらせん対称性 が存在する。超高真空中で TaAs の試料を [001] 面で䢃 開して得られた広域のトポグラフ像が Fig. 3 (c) であ る $(V s=-500 \mathrm{meV}, I S=10 \mathrm{pA})$ 。[001]に沿って擘開 すると As 終端面と Ta 終端面が得られるはずであるが, QPI は As 終端面と符合している。ステップの高さは $2.72 \AA$ であり，C 軸の格子定数の約 $1 / 4$ にあたり，As 層と Ta 層が含まれている事が分かる。我々が測定した 限りでは常に As 終端面が得られており, 恐らくは Ta 終端面は不安定なためだと考えられる。

フェルミエネルギー付近のバンドは，Taの $5 \mathrm{~d}$ 軌道と As の $4 \mathrm{p}$ 軌道に由来する。第一原理計算による As 終端 面の最表面単位格子中に含まれる $V=40 \mathrm{meV}$ の表面状 態の模式図を Fig. 4 (a) に示す。緑丸が [001] 面に射影 されたワイル点である。「点（中心）に近いワイル点は 2 重のワイル点であり, ゾーンエッジに近いワイル点は 1 重である。弧を描くようなフェルミアークが見て取れ る。これはARPES によって得られたバンド構造とも整 合している。Fig. 4 (b) にSSPを示す。

Fig. 3 (d) に示す様に, 格子状に並んだ小さな丸が As 原子である。清浄で平坦な領域に十個程度の不純物 が見て取れ，十字状のものはAs 欠陥と考えらている。 測定温度は $40 \mathrm{~K}$ であり，この範囲に対して $256 \times 256$ のグリッド状に約 1 週間連続で FT-STS を行う事が可能 である。Fig. 3（d）より広い領域に対して $V s=40 \mathrm{meV}$, $I s=120 \mathrm{pA}$ で分光マッピングを行った。Fig. 4 (c) に微 分伝導度マップを, Fig. 4 (d) にFT-STS を示す。不純 物を中心に様々な波紋状の QPI が見て取れる。FT-STS は非常に複雑なパターンを示している。

\section{6. 考察}

得られた FT-STS（Fig. 4（d)）はどの様に理解すれば 良いだろうか。先ずはルーチン通り Fig. 4（b）に示し た最表面単位格子内の表面状態のSSP と比較しょう。 概して類似してはいるものの, SSP はFT-STS ょりも多 くのパターンを示している。当初鏡映対称性など他の対 称性による散乱チャネルの抑制を疑ったが，それらは細 
(a)

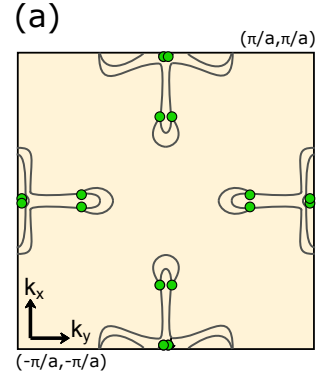

(b)

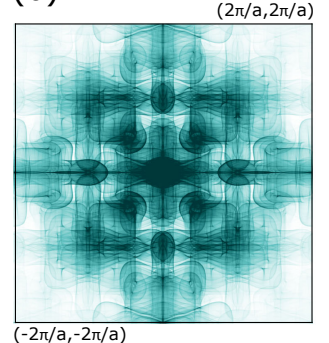

(c)

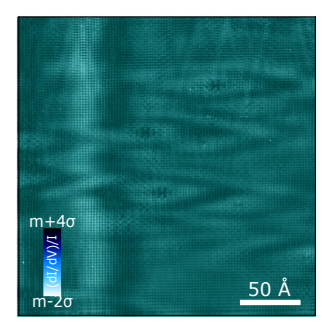

(d)

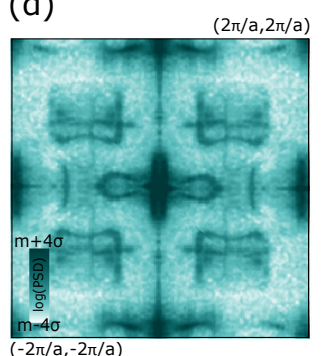

(e)

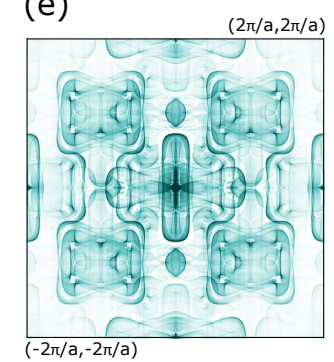

Fig. 4. (color online). (1) Schematic illustration of surface states at $V=40 \mathrm{meV}$ contained in the top most unit cell. Green circles are projected Weyl points. Fermi arcs connecting the Weyl points are present. (2) SSP of surface states at $V=40 \mathrm{meV}$ contained in the top-most unit cell. (c) A large scale STS (bigger area than Fig. 3(d)) at $V_{s}=40 \mathrm{meV}$ and $I_{s}=120 \mathrm{pA}$ (d) FTSTS of STS shown in (c) (e) SSP of surface states at $V=40 \mathrm{meV}$ contained in the top-most As layer.

(a)

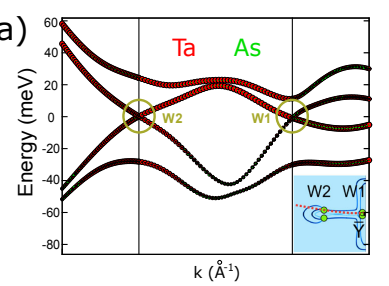

(b)

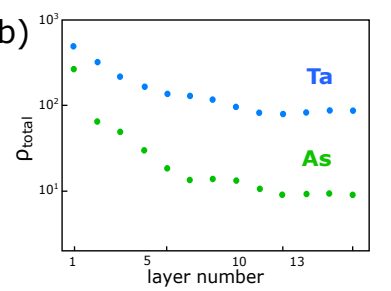

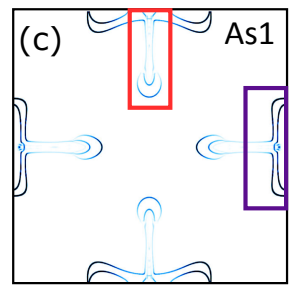

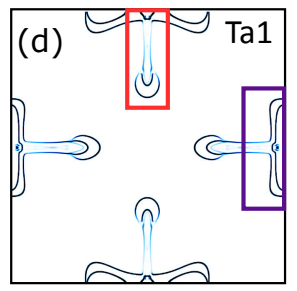

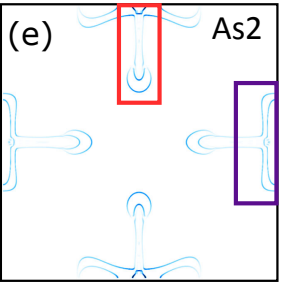

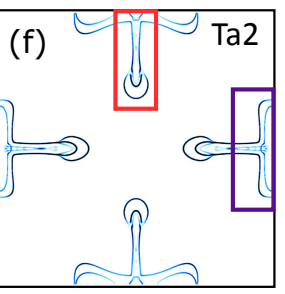

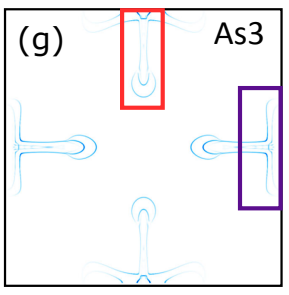

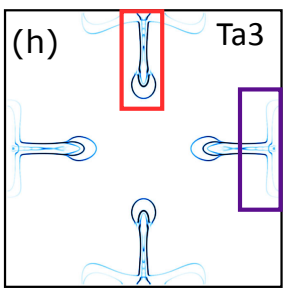

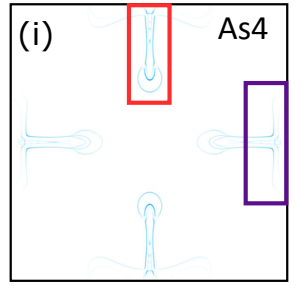

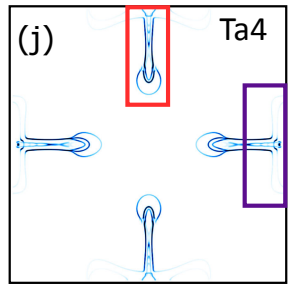

Fig. 5. (color online). (a) The bulk band structure close to the Fermi energy along a line of momenta crossing Weyl points (W1 and W2, see inset). The sizes of the circles indicate the weights of a state on Ta (red) and that on As (green). (c-j) surface states contained in As layer1 to 4 (c, e, g, i) and Ta layer1 to 4 (d, f, h, j), separately, for the top-most layers.

かい定量的な違いを生み出すだけであり，観測された FT-STS を説明出来なかった。

検討した結果, 表面状態の表面深さ依存性が重要であ ると明らかになった。TaAsの単位格子は As と Ta の層 が 4 層積み重なってできる事を思い出すと（Fig. 3 (b)), 最表面単位格子中に含まれる表面状態の全てが観 測された FT-STSに寄与していない可能性がある。 Fig. 5 (a) はワイル点を横切るような経路の分散を示し たものである。赤点と緑点の大きさは各状態を $\mathrm{Ta}$ 原子 とAs 原子に射影した成分の強度を表しており, ワイル 点付近のバルク状態はほほ $\mathrm{Ta}$ 原子に偏っている事が分 かる。DFTによって得られたフェルミ面での表面状態 密度の総和を各 $\mathrm{As}$ 層, Ta 層に射影したものを最表面を 第 1 層として Fig. 5（b）に示す。As 層の状態は表面か ら離れると素早く減少し, 表面に局在する。逆に, Ta 層の状態は深くまで高い状態密度を保ち, バルクの状態 密度に移行している事が分かる。これは前述のワイルコ ーンが Ta 上の状態でほほ構成されている事と整合して
いる。表面フェルミ面を層毎に示したものが Fig. 5 (c)-(j) である。As1 は最表面の As 層, Ta1 はその直下 の $\mathrm{Ta}$ 層を表す。スプーン状の部分は比較的深層まで状 態密度が高く保たれ, 蝶ネクタイ状の部分はより表面に 近い所に局在している事が分かる。そこで, 最上層の As 層に含まれる表面状態を用いて SSP を計算したもの が Fig. 4（e）であり，測定された FT-STS と良く一致す る。

この新奇な FT-STS はどのように理解すれば良いの か。QPI とは定在波であり, 入射波と散乱波と二つの波 数状態によって構成される。表面状態は波数に依存して バルク状態との結合度が違う事を思い出すと, ワイル点 に近い状態ほどバルクの性質が大きくなり, 最表面での $\mathrm{QPI}$ への寄与が弱くなる。Ta原子上の状態はバルクの ワイルコーンと重なりが大きい事を思い出せば, 最上層 の As 原子に存在する表面状態間（蝶ネクタイ間）の $\mathrm{QPI}$ が強く, 次層の $\mathrm{Ta}$ 上の状態（スプーン）を含む QPI が弱く現れると理解できる。つまり, 本結果はワイ 
ル半金属 TaAs の表面-バルク結合性を原子スケールで観 測したものと理解できる。当初, バルクサンプル表面の 原子スケール観察により表面-バルク結合性が観測され るとは予想されていなかった。薄膜ディラック半金属系 での輸送測定による表面バルク結合性を示した実験は 本実験と相補的である ${ }^{11}$ 。

また，本研究に加え，TaAs と NbP[001]面にて STM により準粒子干渉を観測した実験においても多くの知見 が得られている ${ }^{14 \sim 16) 。 ~}$

\section{7.おわりに}

量子論の建設後に量子論の応用として生まれたバンド 理論は, トポロジーの視点を纏い, 昨今のトポロジカル 物質の隆盛をも生み出した。トポロジカル物質相が発現 する系は, 結晶電子に留まらず，極低温原子ガス，フォ トニック結晶，メカニカルメタマテリアルなど，今なお 広がり続けている。ワイル半金属の研究からも分かる様 に，当分野では理論と実験の連携に目覚ましいものがあ り，真空における表面プローブはこれからもトポロジカ ル物質研究の更なる発展に貢献するはずである。

\section{謝 辞}

本研究は András Gyenis, Zhijun Wang, Jian Li, Seong Woo Oh, Shan Jiang, Ni Ni, Andrei Bernevig, Ali Yazdani の各氏との共同研究によって行われました。

\section{文献}

1) N.P. Armitage, E.J. Mele and A. Vishwanath : Rev. Mod. Phys. 90, 015001 (2018).

2) X. Wan, A.M. Turner, A. Vishwanath and S.Y. Savrasov : Phys. Rev. B 83, 205101 (2011).

3) A.A. Burkov and L. Balents : Phys. Rev. Lett. 107, 127205 (2011)
4) H. Weng, C. Fang, Z. Fang, B.A. Bernevig and X. Dai : Phys. Rev. X 5, 011029 (2015).

5) B.Q. Lv, H.M. Weng, B.B. Fu, X.P. Wang, H. Miao, J. Ma, P. Richard, X.C. Huang, L.X. Zhao, G.F. Chen, Z. Fang, X. Dai, T. Qian and H. Ding : Phys. Rev. X 5, 031013 (2015).

6) S.-Y. Xu, I. Belopolski, N. Alidoust, M. Neupane, G. Bian, C. Zhang, R. Sankar, G. Chang, Z. Yuan, C.-C. Lee, S.-M. Huang, H. Zheng, J. Ma, D.S. Sanchez, B. Wang, A. Bansil, F. Chou, P.P. Shibayev, H. Lin, S. Jia and M.Z. Hasan : Science 349, 613 (2015).

7) L.X. Yang, Z.K. Liu, Y. Sun, H. Peng, H.F. Yang, T. Zhang, B. Zhou, Y. Zhang, Y.F. Guo, M. Rahn, D. Prabhakaran, Z. Hussain, S.-K. Mo, C. Felser, B. Yan and Y.L. Chen : Nat. Phys. 11, 728 (2015).

8) H. Inoue, A. Gyenis, Z. Wang, J. Li, S.W. Oh, S. Jiang, N. Ni, B.A. Bernevig and A. Yazdani : Science 351, 1184 (2016).

9) S. Murakami : New J. Phys. 9, 356 (2007).

10) A.C. Potter, I. Kimchi and A. Vishwanath : Nat. Commun. 5, 5161 (2014).

11) P.J.W. Moll, N.L. Nair, T. Helm, A.C. Potter, I. Kimchi, A. Vishwanath and J.G. Analytis : Nature 535, 266 (2016).

12) Y. Hasegawa and P. Avouris : Phys. Rev. Lett. 71, 1071 (1993).

13) M.F. Crommie, C.P. Lutz and D.M. Eigler : Nature 363, 524 (1993).

14) H. Zheng, S.-Y. Xu, G. Bian, C. Guo, G. Chang, D.S. Sanchez, I. Belopolski, C.-C. Lee, S.-M. Huang, X. Zhang, R. Sankar, N. Alidoust, T.-R. Chang, F. Wu, T. Neupert, F. Chou, H.-T. Jeng, N. Yao, A. Bansil, S. Jia, H. Lin and M.Z. Hasan : ACS Nano 10, 1378 (2016).

15) R. Batabyal, N. Morali, N. Avraham, Y. Sun, M. Schmidt, C. Felser, A. Stern, B. Yan and H. Beidenkopf : Sci. Adv. 2, e1600709 (2016).

16) P. Sessi, Y. Sun, T. Bathon, F. Glott, Z. Li, H. Chen, L. Guo, X. Chen, M. Schmidt, C. Felser, B. Yan and M. Bode : Phys. Rev. B 95, 035114 (2017). 